\title{
STUDENTS' PROFESSIONAL DIRECTION TOWARDS ENGINEERING PROFESSIONS AT COMPREHENSIVE SECONDARY SCHOOLS IN THE CONTEXT OF SELF- DETERMINATION
}

\author{
Irena Katane ${ }^{1}$, Edgars Katans ${ }^{2}$, Evita Korna ${ }^{3}$, Ineta Kristovska ${ }^{4}$ \\ ${ }^{1,3}$ Latvia University of Agriculture, Latvia; ${ }^{2}$ IT company "Autentica”, Latvia; \\ ${ }^{4}$ University of Business, Arts and Technology RISEBA, Latvia \\ irena.katane@inbox.lv, edgars.katans@inbox.lv, evita.korna@t2v.lv, ineta.kristovska@btv.lv
}

\begin{abstract}
Graduation is the time when youth have to make important decisions and choose what they want to do after the school, which profession they want to acquire, in which professional field they want to work. This is the first stage of the professional self-determination as the professional self-determination and career selfmanagement is a life-long process. For the purpose of this research an empirical study was performed with an aim to explore the professional self-determination of 12th grade pupils in the establishments of general secondary education, especially focusing attention on engineering professions. For the theoretical and methodological basis of the research the results of theoretical studies in the following directions were used: 1) Self-Determination and Professional Self-Determination; 2) Career Management and Self-Management; 3) Professional Directionality of Personality; 4) Career Guidance, including Career Guidance System at School. Research methods: test for the determination of the professional directionality. Both results of the descriptive and the inferential statistics show that in both schools where the study was carried out there is a profound discrepancy between I want and I am able aspects in the self-assessment of pupils in relation to their future profession.
\end{abstract}

Keywords: engineering professions, professional self-determination, school youth, self-evaluation.

\section{Introduction}

At present one can observe global changes both in society and economy which have a large impact on the labour market. The environment of professions is changing since with the development of science many new technologies appear which we use in our everyday life, therefore there are some professions which do not correspond to modern requirements or disappear from the professional field, and there are new professions which substitute the first. Education has immense importance in the liberalisation of the labour market, since it respects the needs of contemporary society. It also secures sustainable development for future society, because at the present moment schools educate those generations which will determine the competitiveness and sustainability of the state and society in future. Nowadays every individual has to be able to actualise and realise oneself in the continuously changing environment of professions and the labour market. Career development is a lifelong process thus the professional self-determination continues throughout the whole life. Every member of the society, irrespective of being a youth or an adult, must be ready to continue learning during the whole life. Nowadays it is not enough to choose a profession once, usually in one's youth. One must be able to make important decisions several times adapting to the changing environment. In education, synergistic approach has acquired topicality providing a new perspective for the research and promotion of individual's professional self-determination and professional development, which is a non-linear process. Nowadays every individual in the society being a self-developing and selforganising entity must be able to assess one's potential of development, the necessary resources, and must search for opportunities offered by the changing environment. The graduation of school is the time when students must take their first responsible decision, answering questions what they want to do after the school, where to study, which profession to learn, in which professional sphere they want to work after the acquisition of the basic primary or secondary education. This is the first stage of the professional self-determination $[1 ; 2]$.

It is very important for youth to explore oneself, assessing one's knowledge, skills, competences, learning results [3] in relation to one's future intentions, career choice and development targets. It is a vital aspect of professional self-determination, since not always their I am able corresponds to their I want. School students must learn how to plan and manage one's career, therefore they would need assistance in adjusting their competences both to their future intentions and aims in their life, and they also need to take into account which professions are and will be in demand in our society (society needs). 
Owing to the development of equipment and technologies in science and the necessity to implement these developments in practice, the engineering professions are becoming even more demanded. And at the same time continues the trend that insufficient proportion of young people choose engineering professions. A large part of youth is unable to adequately assess their own competences in relation to engineering professions and subjects in the higher education engineering programmes, including mathematics [4]. Experience shows that only a fraction of young people who have the necessary competences and who have sufficiently high self-assessment of these competences choose one of engineering professions.

Aim of the study: to explore the professional self-determination of 12th grade students in the establishments of general secondary education, especially focusing attention on engineering professions.

\section{Materials and methods}

The research serving as a theoretical and methodological basis for our study on the professional self-determination of youth and its facilitation in schools has been performed in four directions:

- Self-Determination and Professional Self-Determination [1-13].

- Career Management and Self-Management [7; 14- 16].

- Professional Directionality of Personality, including Self-Directed Learning [17-24].

- Career Guidance, including Career Guidance System at School [25-29].

The empirical study was carried out in the X town of Latvia. In the first study 88 students of the $12^{\text {th }}$ grade participated who will graduate this year in spring: 53 students from a Gymnasium (grades $12 \mathrm{a}, 12 \mathrm{~b}, 12 \mathrm{c}$ ) and 34 students from a Secondary School (grades $12 \mathrm{a}, 12 \mathrm{~b}$ ).

The students of gymnasiums study in different education programmes: 1) Programme of General Education Direction of General Secondary Education (code of the education programme 31011011); 2) Programme of Mathematics, Natural Sciences and Engineering Direction of General Secondary Education (code of the education programme 31013011 with advanced-level Chemistry); 3) Programme of Mathematics, Natural Sciences and Engineering Direction of General Secondary Education (code of the education programme 31013011 with advanced-level Mathematics). Students at general education secondary schools study in the following programmes: 1) Programme of General Education Direction of General Secondary Education 31011011; 2) Programme of Vocational Direction (Commerce) of General Secondary Education (code of the education programme 31014011). Thus, it can be concluded that most of the students acquire knowledge, skills and competences in a level that is sufficient to choose higher professional education study programmes in engineering.

The study was carried out in the autumn of 2016.

Research methods: For data extraction, a test for the determination of the professional direction was used [30]. The test methodology enables to diagnose: 1) abilities of an individual in one of the fields on the basis of a self-assessment, as well as 2) professional interests, desires and future intentions of an individual. Results acquired in mathematical processing of the test results allow to determine the correlation between I am able and I want, which is very important in the context of professional self-determination and career choice support. The theoretical basis for the test methodology is the research performed by Y.Klimov [10] in the field of the professional selfdetermination psychology including his typology of professions, which covers 5 spheres of professional: 1) Human -Human; 2) Human - Machinery; 3) Human - System of Signs (symbols); 4) Human-Art; 5) Human-Nature.

I. Solomin [30] in his research elaborated the concept of Y.Klimov further distinguishing and scientifically substantiating two groups of professions: 1) executing professions; 2) creative personality professions. Among the engineering professions we were interested particularly in three out of five spheres of professional activity (Table 1), since they are related both to specialisation in engineering professions (for example, technical expert of transport road vehicles, mechanical engineer, energy engineer, engineer in computer control and computer science, software engineer, civil engineer, food technologist etc.), and the typology of future engineers' thinking and general education study courses, for example, Mathematics, Physics, Chemistry, Ecology. It is important to stress that all 
qualifications in engineering professions provided by higher education establishments are related to creative personality professions.

Fields of professional activity in the context of the field of engineering professions

\begin{tabular}{|l|l|}
\hline \multicolumn{1}{|c|}{ Professional orientation } & \multicolumn{1}{c|}{ Professions for a creative personality } \\
\hline Human-Machinery & $\begin{array}{l}\text { Engineer-designer/constructor, engineer-mechanic, civil } \\
\text { engineer, engineer-technologist, technician, flight engineer, } \\
\text { civil aviation pilot }\end{array}$ \\
\hline $\begin{array}{l}\text { Human - Sign (symbols) } \\
\text { System }\end{array}$ & $\begin{array}{l}\text { Software developer, software engineer, civil aviation } \\
\text { steersman/pilot etc. }\end{array}$ \\
\hline Human-Nature & $\begin{array}{l}\text { Mathematician, physicist, chemist, ecologist, forestry } \\
\text { engineer etc. }\end{array}$ \\
\hline
\end{tabular}

The test by I.Solomin was translated and adapted in Latvian and empirically approbated during research in 2010, which took place at Latvian X City Gymnasium. Assoc. professor I.Katane and an MA student S.Gribanova were the authors of this research [32].

During data processing for inferential statistics a Sign test in SPSS (21.0) program was performed. In the beginning, data processing, analysis of results and their assessment was performed in each school separately, then the obtained results were compared between the schools, pointing out common regularities.

\section{Results and discussion}

Data obtained during the test at the Secondary School were collected and processed (Table 2), to obtain descriptive statistics. The results of descriptive statistics show that there is profound discrepancy between I am able and I want aspects in students' self-assessment. Results show that in the professional direction Human-Machinery, 8 students (24\%) have assessed their competencies as appropriate ( $I$ am able) for the acquisition of the higher education in the sphere of engineering, however only 6 students $(18 \%)$ want to acquire profession which is related to machinery. In the professional direction Human-Signs (symbols) system (for example, the profession of a software developer or a software engineer), the occurrence of appropriateness in the assessment is even smaller, namely, only 3 students ( $9 \%$ ) out of total number have assessed their competences, including skills, as appropriate for the profession, but 5 students $(15 \%)$ would like to pursue a career in this profession. Here we can see an opposite discrepancy, the occurrence of I am able appropriateness is smaller than the occurrence of I want.

Table 2

Results of descriptive statistics (Secondary School)

(total number of $12^{\text {th }}$ grade students $n=34$ )

\begin{tabular}{|c|c|c|c|c|}
\hline \multirow{2}{*}{ Sphere of professional direction } & \multicolumn{2}{|c|}{ I want } & \multicolumn{2}{c|}{ I am able } \\
\cline { 2 - 5 } & $\begin{array}{c}\text { Absolute } \\
\text { value }\end{array}$ & $\begin{array}{c}\text { Percentage } \\
\text { ratio }\end{array}$ & $\begin{array}{c}\text { Absolute } \\
\text { value }\end{array}$ & $\begin{array}{c}\text { Percentage } \\
\text { ratio }\end{array}$ \\
\hline Human-Human & 9 & 0.27 & 20 & 0.59 \\
\hline Human-Machinery & 6 & 0.18 & 8 & 0.24 \\
\hline Human-Signs (symbols) system & 5 & 0.15 & 3 & 0.09 \\
\hline Human Art Image & 7 & 0.21 & 3 & 0.09 \\
\hline Human-Nature & 18 & 0.53 & 1 & 0.03 \\
\hline Executive professions (A) & 15 & 0.44 & 15 & 0.44 \\
\hline Creative professions (B) & 23 & 0.68 & 23 & 0.68 \\
\hline
\end{tabular}

The same can be said about the professional direction sphere Human-Nature, where only 1 student $(3 \%)$ considers his/her competences as appropriate for natural sciences, but 18 students $(53 \%)$ would like to work in these professions. Discrepancies between I am able and I want aspects can be observed also in spheres Human-Human and Human-Art Image. 
It is important to stress that the results of the test show that student self-assessment may be related to different fields of professions, thus in many students appropriateness for the profession may be related both to executive and creative professions, therefore the total occurrence of appropriateness both in assessment of I want and I am able does not coincide with the total number of participants (students) (Table 2).

Table 3

Results of the Sign Test (Secondary School)

\begin{tabular}{|c|c|c|}
\hline $\begin{array}{c}\text { Comparable representative } \\
\text { samples }\end{array}$ & Results & $\boldsymbol{N}$ \\
\hline \multirow{4}{*}{ I am able - I want } & Negative Differences (I am able < I want) & 19 \\
\cline { 2 - 3 } & Positive Differences (I am able > I want) & 3 \\
\cline { 2 - 3 } & Ties (I am able = I want) & 12 \\
\cline { 2 - 3 } & Total & 34 \\
\hline
\end{tabular}

In the next stage of data processing in SPSS program (21.0), individual data, I am able and I want, of each respondent from the Secondary School, 12th grade were entered to assess the level of level of matches or discrepancies significance. To obtain inferential statistics, Sign test was used for difference determination. The results of difference determination (Table 3) show that comparing I want set of representative samples with I am able representative samples, out of 34 representative samples match occurred only in 12 representative pairs. Analysing matches between I am able and I want more in detail, it was concluded that: 1$)$ only 1 student $(\approx 3 \%)$ is both able and want to acquire a profession in one of the fields Human-Nature; 2$)$ only 2 students $(\approx 6 \%)$ could be able and want to acquire a profession in one of the fields Human-Signs (symbols) system; 3 ) only in 4 students (12\%) there is a match between their I am able and I want in the professional field Human - Machinery. Thus only 7 students $(21 \%)$ out of 34 students potentially may become engineers in future (Table 6).

The results of inferential statistics obtained in the sign test ( $p$-value $=0.001<\alpha=0.01$ ) show that there are significant differences in the I want and I am able self-assessment in the group of the Secondary School 12th grade students.

Test results on students' professional self-determination at the Gymnasium were also collected and processed. The results of descriptive statistics can also be seen in the Table 4. The obtained results show that in comparison with the Secondary School, at the Gymnasium there is a larger percentage (30\%) of those students, who have assessed their competences (I am able) as appropriate for the professional field Human-Machinery. Comparatively larger is also the percentage (20\%) of those students, who want to acquire a profession in this field (I want). However, also here the discrepancy between I am able and $I$ want can be observed (Table 4).

\section{Results of descriptive statistics (Gymnasium)}

Table 4

(total number of 12grade students $n=54$ )

\begin{tabular}{|c|c|c|c|c|}
\hline \multirow{2}{*}{ Sphere of professional direction } & \multicolumn{2}{|c|}{ I want } & \multicolumn{2}{c|}{ I am able } \\
\cline { 2 - 5 } & $\begin{array}{c}\text { Absolute } \\
\text { value }\end{array}$ & $\begin{array}{c}\text { Percentage } \\
\text { ratio }\end{array}$ & $\begin{array}{c}\text { Absolute } \\
\text { value }\end{array}$ & $\begin{array}{c}\text { Percentage } \\
\text { ratio }\end{array}$ \\
\hline Human-Human & 15 & 0.28 & 32 & 0.59 \\
\hline Human-Machinery & 11 & 0.20 & 16 & 0.30 \\
\hline Human-Signs (symbols) system & 4 & 0.07 & 4 & 0.07 \\
\hline Human Art image & 17 & 0.32 & 4 & 0.07 \\
\hline Human-Nature & 15 & 0.28 & 3 & 0.06 \\
\hline Executive professions (A) & 21 & 0.39 & 21 & 0.39 \\
\hline Creative professions (B) & 39 & 0.72 & 41 & 0.76 \\
\hline
\end{tabular}

The results obtained in the professional field Human -Nature are very similar to the Secondary School (Table 4). The number of student who might work in the field Human - Nature is significantly 
smaller (3 students: $6 \%$ ) than the number of students who would like to acquire one of these professions (15 students: $28 \%$ ).

Only 4 students ( $7 \%$ out of the total number - 54 students) might acquire a profession in the field Human-Signs (symbols) system, as they have relevant competences. Exactly the same number of students would like to acquire one of the professions in this field. However, the obtained results displayed in the Table 4 do not mean that these are one and the same students.

Table 5

Results of the Sign Test (Gymnasium)

\begin{tabular}{|c|c|c|}
\hline $\begin{array}{c}\text { Comparable representative } \\
\text { samples }\end{array}$ & Results & $\boldsymbol{N}$ \\
\hline \multirow{3}{*}{ I am able - I want } & Negative Differences (I am able <I want) & 25 \\
\cline { 2 - 3 } & Positive Differences (I am able >I want) & 3 \\
\cline { 2 - 3 } & Ties (I am able = I want) & 26 \\
\cline { 2 - 3 } & Total & 54 \\
\hline
\end{tabular}

The secondary data processing was necessary to obtain inferential statistics. To find out matches and difference in 54 representative pairs in the set of data in the group of the Gymnasium 12th grade students, comparing I want representatives with I am able representatives a Sign test in the program SPSS (21.0) was used.

The obtained difference determination results show that there are no matches between I am able and $I$ want self-assessment in 28 pairs (Table 5). The results of the Sign test inferential statistics show that among the students of the Gymnasium self-assessment $I$ am able also significantly differs from $I$ want in the self-assessment: $p$-value $=0.000<\alpha=0.001$.

More detailed data analysis shows that despite the fact that in two of the three parallel classes students acquire the secondary education in the Programme of Mathematics, Natural Sciences and Engineering Direction of General Secondary Education (code of the education programme 31013011) with advanced-level Chemistry and the Programme of Mathematics, Natural Sciences and Engineering Direction of General Secondary Education (code of the education programme 31013011) with advanced-level Mathematics: 1$)$ only 2 students $(\approx 4 \%)$ out of 54 said that they wanted and were able to work in the professional field Human-Nature; 2$)$ only 1 student $(\approx 2 \%)$ out of 54 said that he/she could be able and wanted to work in the profession Human- Signs (symbols) system; 3) out of the total number of students 7 students $(13 \%)$ would like and would be able to work in the professional field Human-Machinery (Table 6).

Table 6

Number of students in both schools who are able and want to work in engineering professions

\begin{tabular}{|c|c|c|c|c|}
\hline \multirow{2}{*}{ Field of the professional direction } & \multicolumn{2}{|c|}{$\begin{array}{c}\text { Secondary School } \\
(n=34)\end{array}$} & \multicolumn{2}{c|}{$\begin{array}{c}\text { Gymnasium } \\
(n=54)\end{array}$} \\
\cline { 2 - 5 } & $\begin{array}{c}\text { Absolute } \\
\text { value }\end{array}$ & $\begin{array}{c}\text { Percentage } \\
\text { ratio }\end{array}$ & $\begin{array}{c}\text { Absolute } \\
\text { value }\end{array}$ & $\begin{array}{c}\text { Percentage } \\
\text { ratio }\end{array}$ \\
\hline Human-Machinery & 1 & 3 & 7 & 13 \\
\hline Human-Signs (symbols) system & 2 & 6 & 1 & 2 \\
\hline Human-Nature & 4 & 12 & 2 & 4 \\
\hline Total: & 7 & 21 & 10 & 19 \\
\hline
\end{tabular}

Despite the fact that the status of both schools is different and most of the students acquire different education programmes, results related to engineering professions are quite similar: in both schools, only approximately one fifth of students consider that they would be able and would like to acquire a profession related to engineering sciences. These results suggest two questions-why students have so low self-assessment of their competences, which according to their opinion are not appropriate for engineering professions and why students who would be able to study engineering in the establishments of higher education do not choose engineering professions. 


\section{Conclusions}

Analysing and assessing the obtained test results, the following findings have been made.

1. The results of both descriptive and inferential statistics show that in both schools that participated there is significant discrepancy between the aspects I want and I am able in their self-assessment considering their future profession;

2. There are two kinds of discrepancies between I want and I am able: 1) in both schools participating in the study there are students who assess their competence as appropriate for engineering professions, but do not want to become engineers; 2) there are students who assess their competences as inappropriate for engineering professions, however they would like to acquire a profession in engineering.

3. Both at the Secondary School $59 \%$ (20 students) of students out of the total number in the 12th grades and also $59 \%$ (32 students) students out of the total number at the Gymnasium $12^{\text {th }}$ grades think that their competences at the present moment are more appropriate for the professional field Human-Human not engineering.

4. At the Secondary School, only 7 students (21\%) and 10 students (19\%) at the Gymnasium, i.e. only one fifth of the total number of students in the 12th grades in each school, consider that they could (would be able) and also want to acquire one of engineering professions.

5. This means that in future, offering career choice support to students at both schools, it would be advisable to focus on the following:

- timely facilitation of students' self-exploration and self-assessment in relation to the choice of their future profession;

- meaningful learning in the context of students' future profession, preparing students for selfdirected learning and competence-based learning so that $I$ want aspect would be aligned with $I$ am able aspect;

- to the demand in the labour market, including the demand in engineering professions, so that in the self-assessment of student I want and I am able are aligned with society needs; an assumption can be made that 1) being aware of the considerable demand in engineering professions, students will become more motivated to make their choice in favour of engineering professions; 2) facilitating adequate self-assessment of students' competences, it would be possible to prevent inadequate or lowered self-assessment, thus encouraging students to choose one of engineering professions, because it is likely that fear of insurmountable difficulties during the studies at the university as well as avoidance of responsibility, which is crucial in engineering professions, become the main reasons why students do not choose engineering professions.

6. Research answering the question why pupils, whose competences are appropriate to choose study programmes in engineering sciences for the acquisition of a bachelor degree and engineer qualification, still do not choose these study programmes, neither engineering professions must be continued. Knowing the reasons, it will be possible to provide career choice support.

\section{References}

1. Katane I., Baltusite R., Katans E. Programming engineer professional development and career growth in multi-dimensional view. Proceedings of the International Scientific conference "Engineering for rural development", vol.15, May 25-27, 2016, Jelgava, Latvia, pp. 1182-1192.

2. Katane I., Katans E. Programming specialist's professional development as lifelong selfdetermination and self-organization process. Proceedings of the International Scientific Conference "Society. Integration. Education", May 27-28, 2016 , vol. 2, Rēzekne, Latvia, pp. 535548. [online] [09.03.2017]. Available at: http://dx.doi.org/10.17770/sie2016vol2.1422

3. Briede B. Engineering students' self-assessment of learning outcomes in the context of transformative learning. Proceedings of the International Scientific Conference "Engineering for Rural Development", vol.15, May 25-27, 2016, Jelgava, Latvia, pp.793-799.

4. Vintere A., Briede B. Engineers' mathematics education in the context of sustainable development. Proceedings of the International Scientific Conference "Engineering for Rural Development”, vol.15, May 25.-27, 2016, Jelgava, Latvia, pp.1121-1127. 
5. Deci E. L., Ryan R.M. Self-determination theory: a macrotheory of human motivation, development, and health. Canadian Psychology, vol. 49, No. 3, 2008, pp. 182-185.

6. Izzo, M., \& Lamb, M. P. Self-determination and career development: skills for successful transitions to postesecondary education and employment. National Center for the Study of Postsecondary Educational Supports: A Rehabilitation Research \& Training Center, 2002. [online] [10.03.2017]. Available at: http://jennyhatchjusticeproject.org/node/98

7. Martin, J. E., Mithaug, D. E., Cox, P. etc. Increasing self-determination: teaching students to plan, work, evaluate, and adjust. Exceptional Children, 69, 2003, pp. 431-447. [online] [10.03.2017]. Available at: determination_contracts_2_1.pdf

8. Голованова И.И. Саморазвитие и планирование карьеры. (Self-Development and Career Planning). Казань: Казанский университет, 2013. 196 с. (In Russian).

9. Кибакин, С.В. Управление процессом педагогической поддержки профессионального самоопределения старшеклассников (Management of Pedagogical Support in Professional SelfDetermination of Secondary School Students). Дис. канд. пед. наук. Москва, 2002. (In Russian).

10. Дементьев, И. В. Проблема профессионального самоопределения школьньников в современной профориентации: психологический и педагогический аспект (Problem of Professional Self-Determination of Students in Contemporary Career Guidance: Psychological and Pedagogical Aspect). В сборнике Научные труды Республиканского института высшей школы. Минск: РИВШ, 2009, с. 242-248. (In Russian). [online] [10.03.2017]. Available at: http://elib.bsu.by/handle/123456789/18836.

11. Климов Е.А. Психология профессионального самоопределения (Psychology of Professional Self-Determination). Москва: Издательский центр “Академия”, 2004, 304 с. (In Russian).

12. Пряжников Н.С. Профессиональное самоопределение: теория и практика (Professional Selfdetermination: Theory and Practice). Москва: Академия, 2007. (In Russian).

13. Пряжникова Е. Ю. (2007). Размышления о профессиональном самоопределении молодежи (Thinking about Professional Self-determination of Youth). Вестник практической психологии образования (Messenger of Applied Psychology in Education), 3, 2007, c.42-45. (In Russian).

14. Holland, J. L. Making vocational choices. Odessa, FL: Psychological Assessment Resources, Inc., 1997.

15. Callanan G.A. Individual career management. Greenhaus J.H. and Callanan G.A. (Eds). Encyclopedia of career development. California, SAGE Publications. Thousand Oaks, 2006. pp. 378-380.

16. Peters T. Selbst menagement (Self-Management). Econ - Verlag, 2002. 56 s. (in German)

17. Suess J. Power to the people: why self-management is important. The professional development commons. 2015. [online] [10.03.2017]. Available at: http://er.educause.edu/blogs/2015/9/powerto-the-people-why-self-management-is-important

18. Areglado, R. J., Bradley, R. C., \& Lane, P. S. Learning for life: creating classrooms for selfdirected learning. Thousand Oaks, CA: Corwin Press, Inc., 1996.

19. Boyer S.L., Edmondson D.R., Artis A.B., Fleming D. Self-directed learning: a tool for lifelong learning. Journal of Marketing Education, vol. 36, Issue 1, 2014, pp. 20-32.

20. Chee T.S., Divaharan Sh., Tan L., Mun Zh.H. Self $\square$ directed learning with ICT: theory, practice and assessment. Singapore: Ministry of Education, 2011. 62 p.

21. Posner, F. G. A study of self-directed learning, perceived competence and personal orientation among students in an open alternative high school. Doctoral Dissertation, Denver, CO: University of Denver, 1989.

22. Дьяченко М. И., Кандыбович Л. А. Психология высшей школы (Psychology of Higher Education Institution). Минск: БГУ, 1978. (In Russian). [online] [10.03.2017]. Available at: http://www.detskiysad.ru/ped/vshk14.html

23. Кунц Л.И. Профессиональное направленность и направленность личности (Professional Directionality and Directionality of Personality). Сибирский педагогический журнал, 4, 2013, c.137-140. [online] [10.03.2017]. Available at: http://cyberleninka.ru/article/n/professionalnayanapravlennost-i-napravlennost-lichnosti. (In Russian).

24. Ломакина Э.Н. Профессиональная направленность как механизм психологической готовности к профессиональной деятельности студентов (Professional Directionality as a 
Mechanism of Students' Psychological Readiness for Professional Activities). Сибирский педагогический журнал, 10, 2011, 63-71. (In Russian).

25. Столяренко А.М. (ред). Прикладная юридическая психология (Applied Legal Psychology). Москва: Юнити-Дана, 2000, 639 с. [online] [10.03.2017]. Available at: http://www.pravo.vuzlib.su/book_z1744.html. (In Russian).

26. Athanasou J.A., Van Esbroeck R. (Eds.). International handbook of career guidance. Springer Science + Business Media B.V., 2008, pp. 97-113.

27. Pudule G. Karjeras izglītības vadības pilnveide vispārizglîtojošās skolās Latvijā (Improvement of Career Education Management in General Education Schools in Latvia). Promocijas darbs. Rīga: Latvijas Universitāte, 2013. (In Latvian).

28. Sears S. A definition of career guidance terms: a national vocational guidance association perspective. Vocational Guidance Quarterly, 31(2), 1982, pp.137-143.

29. Zelloth H. Demand for career guidance in low- and middle-income countries: an indicator for the growing need of more effective transition support services. In Rauner F., Smith E., Hauschildt U., Zelloth H. (Eds.) Innovative Apprenticeships: Promoting Successful School-To-Work Trasitions. LIT Verlag Münster, 2009, pp. 103-107.

30. Соколова А. С. Система поддержки формирования и развития карьеры для различных групп населения: зарубежный опыт и возможности его использования в российских условиях (The system of support of career formation and development for different population groups: foreign experience and the possibilities to use it in Russia). Ученые записки Орловского государственного университета: Гуманитарные и социальные науки, 5, 2012, с. 404-406. УДК: 316.6 [online] [10.03.2017]. Available at: http://cyberleninka.ru/article/n/sistemapodderzhki-formirovaniya-i-razvitiya-kariery-dlya-razlichnyh-grupp-naseleniya-zarubezhnyyopyt-i-vozmozhnosti-ego-ispolzovaniya. (In Russian).

31. Соломин И. Л. Современные методы психологической экспресс-диагностики и профессионального консультирования (Contemporary Methods of Rapid Psychological Diagnostics and Career Counselling). Санкт-Петербург: Речь, 2006, 280 с. (In Russian).

32. Gribanova S. Karjeras izglītība skolēnu profesionālās pašnoteikšanās sekmēšanai pamatskolā (Career Education Facilitating Students' Professional Self-Determination at the Basic School). Mağistra darbs (Master's Thesis). Jelgava: Latvijas Lauksaimniecības universitāte, 2010, 92 lpp. (in Latvian) 